\title{
ANALISIS TRANSPORTASI KOTA LHOKSEUMAWE
}

\author{
Said Jalalul Akbar \\ Jurusan Teknik Sipil, Universitas Malikussaleh \\ email: jaakidani@gmail.com
}

\begin{abstract}
Abstrak
Kota Lhokseumawe salah satu kota sedang berkembang di provinsi Aceh, saat ini mengalami kemacetan dan rasa kurang nyaman bagi pengguna jalan di titik tertentu pada ruas jalan dalam kota maupun pinggiran kota, sehingga perlu dilakukan suatu kajian/analisis terhadap sistem transportasi yang sedang berlangsung saat ini. Tujuan penelitian ini ingin mengetahui kondisi faktual sistem transportasi yang sedang diterapkan dan langkah solusi apakah yang seharusnya dilakukan oleh pemerintah kota agar nantinya sesuai dengan perundang-undangan traspotasi. Metode yang digunakan dalam penelitian ini dengan pengamatan langsung di lapangan pada titik-titik tertentu sesuai pedoman serta rujukan yang telah diatur didalam peraturan yang berlaku. Dari hasil penelitian diperoleh beberapa jawaban tentang sistem transportasi yang sedang berlaku yaitu jumlah penduduk yang tidak seimbang dengan ukuran (kapasitas) jalan, banyaknya hambatan samping yang disebabkan oleh para pedangang kaki lima, banyaknya terjadi kecelakaan lalulintas yang disebabkan oleh ulah pengemudi yang pakir disembarang tempat, kurang mematuhi peraturan lalulintas dan banyaknya pengemudi dibawah umur, serta masih kurangnya rambu lalulintas pada titik-titik tertentu. Langkah serta solusi yang perlu dilakukan untuk menanggulangi hal tersebut adalah dengan menambah jaringan jalan pada beberapa daerah tertentu, memperlebar ukuran jalan sesuai kapasitas lalulintas yang dilayani, menambah ramburambu lalulintas pada beberapa tempat dan memeperbaiki kembali ramburambu lama yang telah rusak dan kurang jelas serta memperjelas garis marka jalan pada tempat-tempat tertentu. Untuk meningkatkan kesadaran akan peraturan lalulintas oleh para pengemudi perlu dilakukan sosialisasi melalui media cetak, elektronik maupun stiker-stiker.
\end{abstract}

Kata Kunci : Transportasi, jalan dan lalulintas

\section{Pendahuluan}

Transportasi adalah usaha memindahkan objek dari suatu tempat ketempat lain. Objek yang dipindahkan dapat berupa penumpang, barang, binatang dan lain-lain. Dalam usahanya memindahkan objek diperlukan pengaturan serta kontrol agar objek yang dipindahkan dapat sampai ditempat tujuan dengan selamat, lancar, ekonomis, aman serta nyaman. Transportasi memegang peranan penting bagi kehidupan manusia, hal ini menunjukkan hubungan yang sangat erat dengan gaya hidup (life style), jangkauan dan lokasi dari kegiatan yang produktif, selingan serta barang-barang dan pelayanan yang tersedia untuk dikonsumsi. Kelancaran transportasi (sistem transportasinya benar) dapat membuat suatu daerah (kota) menjadi maju dan berkembang. Dapat dikatakan transportasi adalah salah satu faktor yang menentukan bagi perkembangan hidup manusia. Transportasi yang menyangkut pergerakan orang dan barang pada hakekatnya telah dikenal secara alamiah semenjak manusia ada dibumi, meskipun pergerakan atau perpindahan tersebut masih dilakukan secara sederhana. Sepanjang sejarah transportasi baik volume maupun teknologinya berkembang sangat pesat. Sebagai 
akibat dari adanya kebutuhan pergerakan manusia dan barang, maka timbullah tuntutan untuk menyediakan prasarana dan sarana agar pergerakan tersebut bisa berlangsung dengan kondisi aman, nyaman dan lancar, serta ekonomis dari segi waktu dan biaya.

Kota Lhokseumawe merupakan salah satu kota yang berada dalam Propinsi Aceh dan terletak di sebelah utara propinsi tersebut dengan jumlah penduduk \pm 170.000 jiwa. Sejak ditemukannya minyak bumi dan gas alam tahun pada tahun 1971 pertumbuhan dan perkembangan kota Lhokseumawe semakin hari semakin meningkat, hal tersebut ditandai dengan berdirinya beberapa perusahaan raksasa seperti PT. Asean Aceh Fertilizer (AAF), PT. Pupuk Iskandar Muda (PIM) dan PT. Kertas Kraff Aceh (KKA) pada era tahun 1980 an, Kondisi ini menyebabkan terjadinya urbanisasi dari berbagai daerah dengan tujuan mencari lapangan pekerjaan dan menetap di kota Lhokseumawe. Seiring dengan hal tersebut di atas banyak lahan/areal pertanian, perkebunan dan pertambakan beralih fungsi menjadi tempat tinggal. Akibatnya jumlah penduduk menjadi semakin padat dan pola hidup masyarakat menjadi berubah secara drastis. Berdasarkan uraian diatas perlu dilakukan kajian/analisis terhadap sistem transportasi yang sedang berlangsung saat ini di Kota Lhokseumawe.

Tujuan dari penelitian ini ingin mengetahui kondisi faktual pada sistem transportasi yang sedang diberlakukan oleh pemerintah kota dan langkah serta solusi apakah yang seharusnya dilakukan oleh pemerintah kota nantinya sehingga sesuai dengan prinsip-prinsip serta teori yang telah diatur dalam perundangundangan traspotasi. Metode yang digunakan dalam penelitian ini adalah dengan pengamatan langsung di lapangan pada titik-titik tertentu sesuai pedoman serta rujukan yang telah diatur didalam perundang-undangan yang berlaku.

\section{Tinjauan Pustaka}

Menurut Morlok (1984), transportasi sebagai suatu tidakan, proses atau hal mentransportasikan atau sedang ditransportasikan dan kata kerja to transport berarti memindahkan dari suatu tempat ketempat lain. Engineering atau teknik didefenisikan sebagai penerapan dari sains dan matematika dimana sifat-sifat dari zat dan sumber-sumber energi didalam alam digunakan untuk kepentingan manusia dalam bentuk struktur bangunan, mesin, produksi, sistem, dan prosesproses lainnya. Dengan demikian teknik transportasi dapat diartikan sebagai penerapan dari sain dan matematika dimana sifat-sifat zat dan sumber-sumber energi alam ini dipakai untuk mengangkut penumpang dan barang dengan suatu cara yang berguna bagi manusia. Teknik transportasi sebagai penerapan prinsipprinsip sain dan tehnologi dalam perencanaan, desain fungsional, pengoperasian, dan pengololaan berbagai fasilitas untuk segala bentuk moda transportasi dengan tujuan untuk menjamin pergerakan manusia dan barang yang aman, cepat, nyaman, mudah, ekonomis dan ramah terhadap lingkungan. Teknik lalu lintas salah satu dari cabang dari teknik transportasi, dapat dideskripsikan sebagai sebagai "Bagian dari teknik transportasi yang berhubungan dengan perencanaan, desain geometris, dan pengoperasian lalu lintas jalan (road), jalan umum (street), jalan raya (highway), jaringan-jaringannya, terminal, lahan yang di tempati, dan hubungannya dengan moda transportasi lainnya (Khisty, 2003) 
Sistem adalah suatu bentuk keterkaitan dan keterkaiatan antara satu variabel/komponen dengan variabel/komponen yang lain dalam tatanan yang terstruktur. Tansportasi adalah kegiatan pemindahan penumpang dan barang dari suatu tempat ketempat lain. Dalam transportasi terdapat unsur pergerakan (movement), dan secara fisik terjadi perpindahan tempat atas barang atau penumpang dengan atau tanpa alat angkut ke tempat lain. Pejalan kaki adalah perpindahan orang tanpa alat angkut. Sistem transportasi merupakan suatu bentuk keterikatan dan keterkaitan antara penumpang, barang, prasarana dan sarana yang berinteraksi dalam rangka perpindahan orang atau barang yang tercakup dalam suatu tatanan, baik secara alami maupun buatan/rekayasa (Anonim, 1997)

Tujuan utama dari teknik sistem transportasi adalah untuk menemukan dan menentukan kombinasi yang paling optimum dari sarana transportasi dan metode pengoperasiannya pada suatu daerah tertentu. Apabila daerah tersebut relatif sempit atau luasnya terbatas, seperti pusat pertokoaan atau pergerakan dari tempat tambang ketempat proses barang tambang tadi yang letaknya berdekatan, maka masalah yang dihadapi tidaklah terlalu sukar. Masalah yang dihadapi transportasi yang sebenarnya adalah lebih rumit, yaitu menyangkut daerah yang lebih luas dengan jenis muatan ataupun penumpang yang beragam. Salah satu contoh masalah teknik sistem transportasi adalah perencanaan fasilitas transportasi dimasa yang akan datang di suatu daerah metropolitan ataupun sistem transportasi antar kota untuk keseluruhan propinsi atau negara (Morlok, 1984).

Menurut Anonim (1997), sistem transportasi diselenggarakan dengan maksud untuk mengkoordinasikan proses pergerakan penumpang dan barang dengan mengatur komponen-komponennya dimana prasarana merupakan media untuk proses transportasi sedangkan sarana alat yang digunakan dalam proses transportasi. Alat ini secara konseptual dibedakan dalam dua bentuk yaitu kenderaan dan mengangkut (kabin). Adapun tujuannya adalah agar proses transportasi penumpang dan barang dapat dicapai secara optimum dalam ruang dan waktu tertentu, dengan mempertimbangkan Faktor keamanan, kenyamanan dan kelancaran, serta efisiensi atas waktu dan biaya.

Menurut Morlok (1984), pada dasarnya ada tiga karakteristik utama dari masalah teknik dan perencanaan sistem transportasi yang membuat sistem tersebut cukup sukar untuk dilaksanakan, ini dengan sendirinya menyangkut tiga sistem dasar yaitu:

a. Daerah yang harus direncanakan menyangkut ribuan ataupun jutaan perjalanan penduduk dengan jumlah angkutan yang berbeda-beda,

b. Dengan tersedianya beragam cara dalam teknologi transportasi dengan beragam cara operasi ataupun harga, terdapat banyak cara untuk mengubah sistem transportasi di daerah tersebut,

c. Tujuan yang hendak dicapai dengan peningkatan sistem transportasi sering kali sukar didefenisikan dengan angka, dan dengan sendirinya tidak hanya menyangkut soal waktu perjalanan seseorang.

Menurut Khisty (2003), bentuk fisik dari kebanyakan sistem transportasi tersusun atas empat elemen dasar yaitu: 
a. Sarana perhubungan (link): Jalan raya atau jalur yang menghubungkan dua titik atau lebih, pipa, jalur ban berjalan (belt conveyor), jalur laut, jalur penerbangan juga dapat dikatagorikan sebagai sarana perhubungan,

b. Kenderaan: alat yang memindahkan manusia dan barang dari satu titik ke titik lain disepanjang sarana perhubungan seperti mobil, bis, kapal, pesawat terbang, ban berjalan (belt conveyor) dan kabel

c. Terminal: Titik-titik dimana perjalanan orang dan orang dimulai atau berakhir. seperti garasi mobil, lapangan parkir, gudang bongkar-muat, terminal bis, dan bandar udara.

d. Manajemen dan tenaga kerja: orang-orang yang membuat, mengoperasikan, mengatur dan memelihara sarana perhubungan, kenderaan dan terminal.

Keempat elemen di atas berinteraksi dengan manusia, sebagai pengguna maupun non pengguna sistem, dan berinteraksi pula dengan lingkungan. Perilaku sub-sistem fisik, sub-sistem manusia dan sub-sistem lingkungan sangatlah rumit karena melibatkan interaksi manusia sebagai pengendara dan non-pengendara yang menggunakan berbagai jenis kenderaan dengan karakter dan kinerja berbeda-beda dan dengan karakteristk fisik yang juga berbeda dalam kondisi lingkungan yang juga sangat beragam. berikut:

Sistem transportasi dapat dievaluasi berdasarkan tiga atribut dasar sebagai

a. Penyebaran (ubiquity): Jumlah aksebilitas untuk dapat menjangkau sistem, arah jalur diantara titik-titik akses dan keluwesan sistem untuk dapat mengatasi beraneka ragam kondisi lalu lintas. Jalan raya lebih tersebar dimana-mana dibanding jalan kereta api, dan ketidakfleksibelannya. Kendatipun demikian, didalam moda jalan raya (higway), jalan tol lebih kecil penyebarannya dibandingkan dengan jalan raya dan jalan,

b. Mobilitas: Kuantitas yang dapat ditangani. Kapasitas satu sistem dalam mengatasi lalu lintas dan kecepatan adalah dua variabel yang berhubungan dengan mobilitas. Disini sekali lagi, jalan tol memiliki mobilitas yang lebih tinggi dibandingkan jalan raya. Transportasi air mungkin saja memiliki kecepatan yang relatif rendah, tapi kapasitas perkenderaannya cukup tinggi. Dipihak lain sistem perkeretaapian mungkin saja memiliki kecepatan yang tinggi serta kapasitas yang besar.

c. Efisiensi: Hubungan antara biaya transpor dan produktifitas dari suatu sistem. Biaya langsung suatu sistem terdiri dari modal dan biaya operasional, sedangkan biaya tak langsung terdiri dari biaya yang muncul akibat dampak yang merugikan dan biaya tak terduga, seperti biaya keselamatan. Setiap moda transportasi mungkin saja efisiensi dalam beberapa aspek namun tidak efisien dalam aspek lainnya.

Menurut Morlok (1984), suatu tehnologi transportasi harus dapat melakukan hal-hal sebagai beriku:

a. Membuat suatu objek menjadi lebih mudah diangkut, dan dapat diangkut tanpa menimbulkan kerusakan. Sebagai contoh suatu hasil produksi tidak dapat diangkat hanya dengan menggulingkan, menyeret atau mengapungkannya, tetapi harus diangkat dengan cara tertentu yang tepat, supaya tidak rusak, 
b. Menyediakan kontrol dari gerakan yang terjadi, dengan pemakaian daya secukupnya agar dapat mempercepat ataupun memperlambat objek tersebut, mengatasi hambatan-hambatan yang bisa terjadi dan mengarahkan objek tersebut tanpa kerusakan. Kontrol gerakan tadi disebut lokomosi (lokomotion). Dalam banyak hal ini dapat dilakukan dengan pemakaian gaya-gaya mekanis yang bekerja pada objek tadi, menggerakkannya melalui jalur jalan tertentu, selain melindunginya. Pemakaian gaya ini harus dapat dikontrol sehingga objek dapat bergerak tanpa menyinggung objek lain yang mungkin ada jalur jalan yang sama, yang dapat menyebabkan kerusakan yang potensial,

c. Melindungi objek dari kerusakan atau kehancuran yang dapat terjadi sebagai akibat samping dari pergerkan tadi. Hal ini penting terutama untuk benda hidup atau bahan makanan, dimana pemeliharaan berupa temperatur lingkungan yang tepat, tekanan kelembaban dan sebagainya memegang peranan penting dalam mempertahankan nilai benda tersebut.

Permasalahan transportasi dan teknik perencanaan mengalami revolusi yang pesat sejak 1980-an. Pada saat ini dirasakan masih banyak permasalahan transportasi yang sebenarnya sudah terjadi sejak 1960-an, misalnya kemacetan polusi udara dan suara, kecelakaan dan tundaan. Permasalahan transportasi yang sudah ada sejak dulu bisa masih dijumpai pada masa sekarang, tetapi dengan tingkat kualitas yang jauh lebih parah dan kuantitas yang jauh lebih besar, mungkin saja mempunyai bentuk lain yang jauh lebih kompleks karena semakin banyaknya pihak yang terkait sehingga sulit diatasi. Di Indonesia permasalahan transportasi sudah sedemikian parahnya, khususnya di beberapa kota besar seperti DKI Jakarta, Surabaya, Medan, dan Bandung. Kota yang berpenduduk lebih dari 1-2 juta jiwa. Pada akhir tahun 2000 diperkirakan hampir semua ibu kota propinsi dan beberapa ibu kota kabupaten akan berpenduduk di atas 1-2 juta jiwa sehingga permasalahan transportasi tidak bisa dihindarkan. Hal ini merupakan lampu merah bagi pembina daerah perkotaan di Indonesia karena akan dihadapkan pada permasalahan baru yang memerlukan pemecahan yang baru pula yaitu permasalahan transportasi perkotaan. Kota kecil juga mempunyai permasalan transportasi yang perlu pemecahan secara dini pula, namun pada umumnya masih dalam sklala kecil dan pemecahannya tidak memerlukan biaya besar dan waktu lama. Dengan demikian, perencanaan dan permodelan transportasi dalam merencanakan pembangunan sistem prasarana transportasi, pengembangan wilayah dan lainnya menjadi semakin terlihat nyata (Tamin, 2000).

Ruang lingkup permasalahan transportasi telah bertambah luas dan permasalahannya itu sendiri bertambah parah, baik di negara maju (industri) maupun dinegara sedang berkembang. Terbatasnya bahan bakar secara temporer bukanlah permasalahan yang parah, akan tetapi peningkatan arus lalu lintas serta kebutuhan akan transportasi telah menghasilkan kemacetan, tundaan, kecelakaan, dan permasalahan lingkungan yang telah berada di atas ambang batas. Permasalahan ini tidak hanya terbatas pada jalan raya saja (Tamin, 2000).

Volume lalu lintas adalah jumlah kenderaan yang melalui suatu titik setiap waktu (Sukirman, 1994). Arus lalulintas adalah jumlah kenderaan bermotor yang melalui satu titik pada jalan persatuan waktu, dinyatakan dalam kend/jam (Manual 
Kapasitas Jalan Indonesia, 1997). Kapasitas adalah arus lalulintas maksimum yang dapat dipertahankan pada suatu bagian badan jalan dalam kondisi tertentu (kenderaan/jam atau smp/jam). Derajat kejenuhan yaitu rasio arus lalu lintas terhadap kapasitas. Tundaan yaitu waktu tempuh tambahan yang diperlukan untuk melewati suatu simpang dibandingkan tanpa melewati suatu simpang (Manual Kapasitas Jalan Indonesia, 1997). Kecelakaan lalulintas merupakan peristiwa yang tidak diharapkan yang melibatkan paling sedikit satu kenderaan bermotor pada suatu ruas jalan dan mengakibatkan kerugian material sampai menelan korban jiwa (Kadiyali, 1983).

Perubahan aliran lalulintas (arus lalulintas) Kota Lhokseumawe bukanlah solusi untuk menjawab kemacetan yang selama ini terjadi di Kota tersebut. Aliran lalulintas yang sedang berlangsung saat ini di kota Lhokseumawe sudah tepat (Widari, 2010).

\section{Metode Penelitian}

Metode yang digunakan dalam penelitian ini adalah dengan cara pengamatan langsung di lapangan pada titik-titik tertentu sesuai pedoman serta rujukan yang telah diatur didalam perundang-undangan yang berlaku, yaitu melakukan observasi pada jalan-jalan utama (protokol), jalan lingkungan yang berhubungan langsung dengan jalan utama, daerah bangkitan perjalanan (jumlah perjalanan yang dibangkitkan oleh suatu zona atau suatu pusat kegiatan) dan daerah tarikan (pasar, tempat hiburan dan lain-lainnya). Hasil pengamatan tersebut akan dibandingkan dengan dasar-dasar teori yang telah dikeluarkan (disahkan) oleh para ahli transportasi, baik dalam negeri maupun dari luar negeri.

\section{Hasil dan Pembahasan}

\subsection{Hasil Penelitian}

Hasil penelitian (pengamatan) langsung di lapangan pada beberapa ruas jalan (titik-titik tertentu) serta hasil wawancara (interview) dengan beberapa responden yang terdiri dari representatif pengemudi maupun masyarakat biasa sebagai pengguna jalan setiap harinya, memperlihatkan bahwa telah terjadi kemacetan, dan sudah terasa tidak nyaman saat melakukan perjalanan. Hal tersebut disebabkan oleh beberapa faktor diantaranya; pertama ketidak seimbangan antara jumlah penduduk dengan ukuran (kapasitas) jalan yang menyebabkan pergerakan lalulintas menjadi lambat dan pada titik tertentu terjadi kemacetan. Kedua, banyaknya hambatan samping yang disebabkan oleh para pedagang kaki lima juga menyebabkan pergerakan lalulintas menjadi lambat dan sering terjadi kemacetan. Kitiga, banyaknya terjadi kecelakaan lalulintas yang disebabkan oleh pengguna jalan yang memarkir kenderaan roda 2 maupun roda 4 pada sembarang tempat di ruas-ruas jalan, kurangnya kesadaran dalam mematuhi peraturan lalulintas dan banyaknya pengemudi kenderaan khususnya roda 2 usia masih dibawah umur. Keempat, masih kurangnya rambu lalu lintas pada titik-titik tertentu juga menyebabkan sering terjadinya kecelakaan pada titik tertentu pula. Hasil akhir yang diperoleh bahwa terjadinya kemacetan lalulintas di kota Lhokseumawe juga diakibatkan oleh pengaturan arus lalulintas (aliran lalulintas) pada ruas-ruas jalan pada tititk-titik tertentu masih kurang tepat. 


\subsection{Pembahasan}

Berdasarkan hasil diatas jelas bahwa pertumbuhan penduduk dan bertambahnya masyarakat yang menggunakan kenderaan (mobil dan sepeda bermotor) berefek kepada semakin ramainya pemakai jalan (Volume lalu lintas bertambah). Pemakaian jalan tersebut bisa beragam jenis keperluan (ke kantor, ke sekolah, ke pasar, ke tempat hiburan dan lain-lain). Sehingga kapasitas jalan tidak sesuai lagi, yang akhirnya terjadi kemacetan (perlambatan) dan tingkat kecelakaan pun bertambah. Hambatan samping seperti pedagang kaki lima yang berjualan diatas bahu jalan bahkan ada yang naik ke pinggiran badan jalan merupakan pelanggaran yang sangat besar didalam ilmu transportasi (hukum transportasi), hal tersebut disamping menyebabkan terjadinya kemacetan karena pembeli juga bisa menyebabkan terjadinya kecelakaan yang akhirnya bisa berakibat kepada korban jiwa./nyawa. Hambatan samping juga bisa diakibatkan oleh pemarkiran kenderaan pada bahu jalan atau pinggiran badan jalan. Hal tersebut disamping mempersempit ruas jalan yang menyebabkan pengemudi sukar dalam mengemudi juga menghalangi pandangan pengemudi baik ke depan maupun ke belakang yang akhirnya juga berakibat pada terjadinya kecelakaan lalulintas.

Selanjutnya banyaknya pengemudi saat ini masih dibawah umur yang tidak memahami aturan lalu lintas, melakukan kebut-kubutan tanpa memperdulikan rambu-rambu lalulintas yang telah dipasang oleh para petugas yang berwewenang sehingga mengganggu masyarakat pengguna jalan yang berpotensi terhadap terjadinya kecelakaan. Masalah rambu lalulintas pada dasarnya sudah terpasang pada jalan yang ada namun pada ruas jalan yang baru dibangun belum terpasang, hal ini mungkin dalam tahap pegerjaan akhir (finishing). Pada beberapa ruas jalan, kondisi rambu perlu diperbaiki karena di beberapa titik tertentu (ruas jalan) rambu-rambunya telah rusak (kurang jelas/kabur, patah). Dari aspek manajemen lalulintas, aliran arus lalulintas masih kurang tepat pada titik-titik tertentu. Berdasarkan hal tersebut menggambarkan bahwa kemacetan yang terjadi tidak dipengaruhi oleh pengaturan arus lalulintas.

Langkah serta solusi yang perlu dilakukan untuk menanggulangi hal tersebut adalah dengan menambahkan jaringan jalan (membuka jalan baru) pada beberapa daerah tertentu, memperlebar ukuran jalan sesuai kapasitas lalulintas yang dilayani jalan tersebut. Kemudian menambah rambu-rambu lalulintas pada beberapa tempat dan memeperbaiki kembali rambu-rambu lama yang telah rusak dan kurang jelas serta memperbaiki garis marka jalan pada tempat-tempat tertentu. Untuk meningkatkan kesadaran akan peraturan lalulintas oleh para pengemudi maka perlu dilakukan sosialisasi melalui media cetak, elektronik dan stiker-stiker.

\section{Kesimpulan}

Berdasarkan hasil penelitian yang dilakukan dapat diambil beberapa kesimpulan sebagai berikut:

1. Kondisi saat ini menunjukkan bahwa telah terjadi kemacetan dan ketidaknyamanan bagi pengendara jalan

2. Beberapa faktor yang menyebabkan terjadinya kemacetan diantaranya jumlah penduduk yang tidak seimbang dengan ukuran (kapasitas) jalan, menyebabkan pergerakan lalulintas menjadi lambat dan pada titik tertentu terjadi kemacetan, 
Banyaknya hambatan samping yang disebabkan oleh para pedangang kaki lima juga menyebabkan pergerakan lalulintas menjadi lambat dan sering terjadi kemacetan, banyaknya terjadi kecelakaan lalulintas yang disebabkan pengemudi yang memarkirkan kenderaan pada sembarang tempat di ruas jalan, banyaknya pengemudi kenderaan khususnya roda 2 yang usianya masih dibawah umur, dan masih kurangnya rambu lalulintas pada titik-titik tertentu

3. Kurangnya kesadaran dalam mematuhi peraturan lalulintas oleh pengguna jalan jalan khususnya kaum remaja.

Dari kondisi di atas, dapat diberikan beberapa rekomendasi sebagai masukan bagi multi stake holders sebagai berikut:

1. Pemerintah kota perlu melakukan penambahan jaringan jalan (membuka jalan baru) pada beberapa daerah tertentu, memperlebar ukuran jalan sesuai kapasitas lalu lintas yang dilayani, kemudian menambah rambu-rambu lalulintas pada beberapa tempat dan memeperbaiki kembali rambu-rambu lama yang telah rusak dan kurang jelas serta memperbaiki garis marka jalan pada tempat-tempat tertentu.

2. Untuk meningkatkan kesadaran terhadap peraturan lalulintas bagi pengguna jalan perlu dilakukan sosialisasi melalui media cetak, elektronik dan stikerstiker.

3. Petugas polisi lalu lintas diharapkan dapat menertibkan kaum remaja yang ugal-ugalan serta kebut-kebutan dalam mengendarai sepeda motor.

\section{Daftar Kepustakaan}

1. Anonim, 1997, Manual Kapasitas Jalan Indonesia 1997, Direktorat Jenderal Bina Marga, Bandung

2. Anonim, 1997, Sistem Transportasi 1997, Penataran Dosen Perguruan tinggi Swasta, Oleh Direktorat Perguruan Tinggi Swasta, Jakarta

3. Kadiyali, L.R, 1983, Traffic Engineering and Transport Planning, Khanna Publishers, Delhi

4. Khisty, C.J., Lall. B.K, 2003, Dasar-dasar Rekayasa Transportasi, Jilid I, Penerbit Erlangga, Jakarta.

5. Morlok, E.K, 1984, Pengantar Teknik dan Perencanaan Transportasi, Penerbit Erlangga, Jakarta.

6. Sukirman, S, 1994, Dasar-dasar Perencanaan Geometrik Jalan, Penerbit Nova, Bandung

7. Tamin, O.Z, 2000, Perencanaan dan Pemodelan Transportasi, Edisi Kedua, Penerbit ITB, Bandung

8. Widari, L.A, 2010, Evaluasi Kinerja Jalan Akibat Perubahan Aliran Lalulintas Kota Lhokseumawe, Tesis S2, MTS Universitas Syah Kuala 